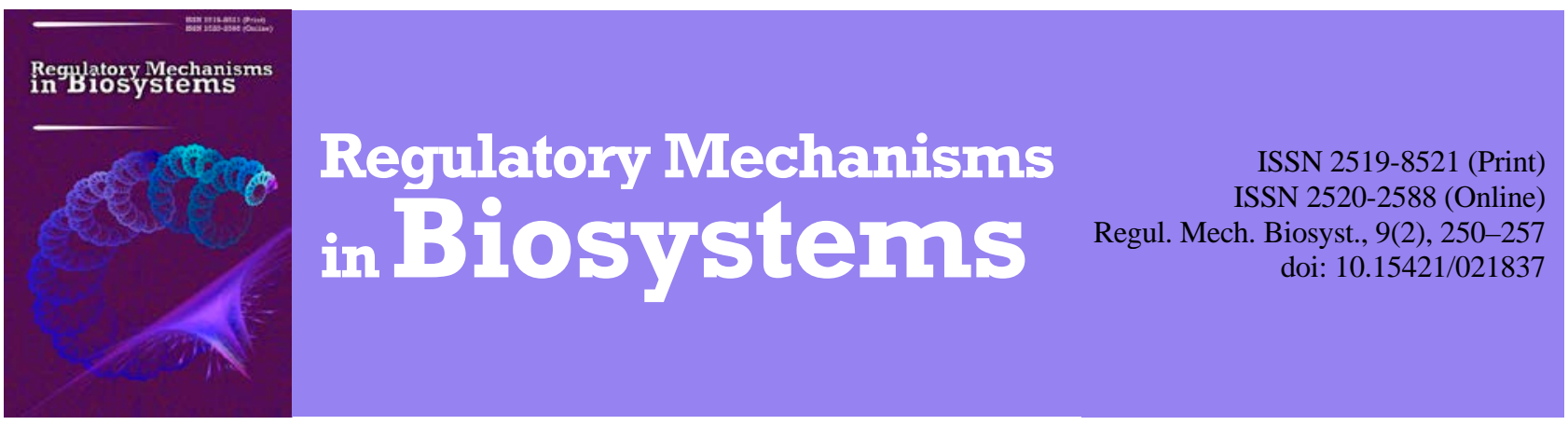

\title{
Triticum spelta: Origin, biological characteristics and perspectives for use in breeding and agriculture
}

\author{
L. M. Babenko*, H. M. Hospodarenko**, R. V. Rozhkov***, Y. F. Pariy***, \\ M. F. Pariy***, A. V. Babenko*, I. V. Kosakivska* \\ *M. G. Kholodny Institute of Botany, Kyiv, Ukraine \\ **Uman National University of Horticulture, Uman, Ukraine \\ ***All-Ukrainian Scientific Institute of Breeding, Kyiv, Ukraine
}

\section{Article info}

Received 07.04.2018

Received in revised form 11.05.2018

Accepted 14.05.2018

M. G. Kholodny Institute of Botany, Tereshchenkivska st. 2, Kyiv, 01601, Ukraine. Tel.: +38-050-358-27-90. E-mail:

lilia.babenko@gmail.com

Uman National University of Horticulture, Institutska st., 1 Uman, 20300, Ukraine. Tel: +38-047-444-69-89. E-mail: udau@udau.edu.ua

All-Ukrainian Scientific Institute of Breeding, Vasilkivska st., 30 Kyiv, 03022, Ukraine. Tel: +38-044-507-11-70.

E-mail:info@vnis.com.ua
Babenko, L. M., Hospodarenko, H. M., Rozhkov, R. V., Pariy, Y. F., Pariy, M. F., Babenko, A. V., \& Kosakivska, I. V. (2018). Triticum spelta: Origin, biological characteristics and perspectives for use in breeding and agriculture. Regulatory Mechanisms in Biosystems, 9(2), 250-257. doi:10.15421/021837

In today's wheat production, the trends focused on the revival, selection and implementation of forgotten regional grain crops, the so-called "antique" cereals, have been clearly identified. One of these is the ancient hexaploid species of wheat - spelt (Triticum spelta). One of the main reasons that have contributed to the revival of this type of wheat in recent years is its tolerance to growing conditions and capacity to endure the natural and climatic factors of the environment, which allows it to be grown without an excessive use of plant protection products. It is precisely because of this feature that hulled wheat is referred to as "environmentally friendly". Spelt is capable of yielding stable crops without strict adherence to the production technology and may be a great alternative to soft wheat. The growth in demand for this crop is also due to a complex of economic and valuable traits inherited from its wild ancestors. This review analyzes and summarizes the information about the origin of spelt, presents biological characteristics, discusses the perspectives for using the species in breeding work when implementing interspecific hybridization and compares the structure and genome evolution. The achievements on the revival of spelt as an independent species and its use as a source of economic and valuable traits in breeding programs of crosses with soft wheat are highlighted, examples of successful use of the economic and valuable traits of spelt for the improvement and creation of new high-quality wheat varieties are presented. Data on this superiority of grain from this species over that of genetically close wheat species are presented. The varietals' characteristics for spelt varieties of Ukrainian selection are given. Such important spelt characteristics as resistance to biotic and abiotic stressors, high quality grain composition and yield have been analyzed.

Keywords: hulled wheat; free-threshing wheat; phylogeny; wheat genome; economically essential features; selection process

\section{Triticum spelta: походження, біологічна характеристика, перспективи використання в селекції та сільському господарстві}

\author{
Л. М. Бабенко*, Г. М. Господаренко**, Р. В. Рожков***, Я. Ф. Парій***, \\ М. Ф. Парій***, А. В. Бабенко*, І. В. Косаківська*
}

* Інститут ботаніки імені М. Г. Холодного, Київ, Украӥна

** Уманський національний університет садівництва, Умань, Украӥна

***Всеукраӥнський науковий інститут селекиїі, Київ, Украӥна

У сучасному виробництві пшениці чітко позначилися тенденції, зосереджені на відродженні, селекції та впровадженні забутих регіональних зернових культур, так званих «античних» злаків. Один із таких злаків - стародавній гексаплоїдний вид пшениці - спельта (Triticum spelta). Спельта невимоглива, росте на малородючих грунтах, стійка до холоду, надмірного зволоження, добре схрещується 3 тетраплоїдними пшеницями, завдяки чому використовується у селекційних програмах для поліпшення твердої та м’якої пшениць. Увага до спельти у країнах Європи зумовлена ії придатністю до маловитратного органічного землеробства, харчовою та технологічною якістю. Використання спельти, як джерела з високим вмістом білка багатого незамінними амінокислотам, для поліпшення технологічного потенціалу борошна під час виробництва хліба, досить перспективне. Основна причина, що сприяла відродженню спельти, - ії невибагливість до умов культивування та витривалість до природно-кліматичних чинників середовища. Спельта не потребує надмірного застосування засобів захисту рослин, через що ії називають «екологічно дружньою». В огляді проаналізовано та узагальнено відомості про походження та поширення спельти, наведено схему еволюції поліплоїдних видів пшениць, відомості про генетичне різноманіття та біологічні ознаки спельти, обговорено 
перспективи використання виду в селекційній роботі для здійснення міжвидової гібридизації та порівняння будови та еволюції геномів. Висвітлено досягнення 3 відродження спельти як самостійної культури та використання виду в селекційних програмах схрещувань із пшеницею м'якою, наведено приклади успішного використання господарсько-цінних ознак спельти для поліпшення та створення нових високопродуктивних сортів пшениці. Подано відомості про переваги зерна цієї культури над генетично спорідненими видами пшениці. Наведено сортові характеристики спельти української селекції. Проаналізовано такі важливі показники спельти як стійкість до біотичних та абіотичних стресорів, якісний склад зерна, врожайність.

Ключові слова: плівчаста пшениця; голозерна пшениця; філогенія; геном пшениці; господарсько-цінні ознаки; селекційний процес

\section{Ветуп}

Пшениця належить до головних зернових культур в Україні та світі. ІІї справедливо вважають рослиною культурного землеробства - вона дає стійкі врожаї тільки за високого рівня агротехнології. Важливий елемент технології її вирощування, котрий впливає на продуктивність, - використання високоврожайних сортів, стійких до біотичних і абіотичних стресорів (Morgun et al., 2016). Розвиток аграрної галузі, що відбувся впродовж останніх двох століть, мав одним із наслідків генетичну ерозію культурних рослин, яка чи не найбільше позначилась на пшениці. Припинено або зведено до мінімуму культивування всіх видів роду Triticum, окрім T. aestivum L. та T. durum Desf., що спричинило звуження різноманіття генів, які зумовлюють стійкість до біотичних і абіотичних стресорів (Faris, 2014). Посіви пшениці стали вразливими, а обсяги та якість урожаю - нестабільними. Нині найпоширеніші за площами та валовими зборами - T. aestivum i T. durum (Goncharov \& Kondratenko, 2008; Tverdohlib \& Boguslavs'kij, 2012).

T. aestivum вирощується на площі майже 240 млн га. Таких обсягів не займає жодна інша зернова культура. За рахунок зростання чисельності населення у світі до 2030 року попит на пшеницю, як очікується, збільшиться на 40\% (Dixon et al., 2009). Для задоволення харчових потреб необхідне щорічне збільшення врожайності на $2 \%$. Проте середньорічні темпи виробництва зерна пшениці значно відстають від темпів росту населення планети. Зростаючий дисбаланс можливо скоротити збільшенням виробництва зерна як за рахунок розширення посівних площ, так і шляхом підвищення врожайності. Перевага віддається саме підвищенню врожайності, оскільки посівні площі у багатьох регіонах Землі досягли або перевищили межі екологічної безпеки (Reynolds et al., 2001). Ця мета може бути досягнута генетичним поліпшенням і поглибленням розуміння біологічних процесів рослини. Розширення наших знань і розуміння еволюції пшениці, включаючи генетичні механізми, що лежать в основі базових процесів доместикації, які сформували теперішню пшеницю, може забезпечити нові ключі до розуміння того, як генетичне різноманіття, доступне прабатькам дикої пшениці, може бути використане для ініціації нової сільськогосподарської революції в умовах мінливого клімату (Faris, 2009).

На території України за впливу природних і антропогенних факторів із поступово зростаючою частотою набувають певної реальності зміни клімату, які посилюють контрастність погодних умов між роками та окремими періодами року. В найближчому майбутньому прогнозуються аномально холодні зими з різкими перепадами температур, нестачею снігового покриву, частими відлигами, що сприяють утворенню льодової кірки (Ivashhenko \& Ivashhenko, 2008). Зимові відлиги, які чергуються 3 раптовими морозами, завдають реальної шкоди та знижують урожайність озимих злаків, для яких умови перезимівлі - визначальні у процесі вегетації. Раннє настання метеорологічної весни збільшує ймовірність ушкодження рослин внаслідок весняних заморозків. Через несприятливі екологічні чинники спостерігається тенденція до зниження виробництва зерна пшениці. Вважається, що до 50\% урожаю втрачається тільки через вплив абіотичних стресорів (екстремальні температури, посуха, засолення, важкі метали, ультрафіолетове опромінення тощо). Ще 10$30 \%$ врожаю може бути втрачено внаслідок біотичних чинників (Morgun \& Major, 2009; Morgun et al., 2016). Інтенсивна селекція, спрямована на підвищення врожайності, спричинила значне збіднення генофонду пшениці, що спонукало вчених до пошуку природних джерел господарсько-цінних ознак для іï поліпшення.
Розвиток культури землеробства та споживання, особливо у провідних країнах світу, викликав усвідомлення цих та інших негативних результатів генетичної ерозії та привернув увагу до видового та внутрішньовидового різноманіття пшениці. Щодалі активніше використовують місцеві форми та сорти пшениці добре адаптовані до умов вирощування (так званий первинний генофонд), види пшениці іншого рівня плоїдності, представники близькоспорідненого роду Aegilops (вторинний генофонд), а також види інших родів - Agropyron, Secale, Hordeum (третинний генофонд) (Golik et al., 2016). При цьому значну увагу приділяють спельті. Спельта невимоглива до умов вирощування, росте на малородючих грунтах, стійка до холоду та надмірного зволоження (Morgun et al., 2015), добре схрещується $з$ тетраплоїдними пшеницями, завдяки чому широко використовується в селекційних програмах для покращення твердої та м'якої пшениць (Tverdohlib \& Boguslavs'kij, 2012). Увага до цієї культури у країнах Європи зумовлена її придатністю до маловитратного органічного землеробства, харчовою та технологічною якістю, що дозволяє частково замінити спельтою традиційно домінуючі пшениці (Golik et al., 2016). Останнім часом стає актуальним збагачення харчових продуктів компонентами різних зернових культур. Тому використання спельти як джерела 3 високим умістом білка, багатого незамінними амінокислотами, для поліпшення технологічного потенціалу борошна під час виробництва хліба досить перспективне (Podprjatov \& Jashhuk, 2013; Hospodarenko et al., 2016). Мета огляду - аналіз і узагальнення відомостей про істоpiю походження T. spelta, біологічні характеристики та перспективи використання спельти у селекційній роботі для здійснення міжвидової гібридизації та порівняльного вивчення будови та еволюції геномів пшениці.

\section{Походження та історія поширення спельти}

Питання філогенії спельти нерозривно пов'язане 3 виникненням загалом гексаплоїдних видів, $і$ до цього часу немає однозначності поглядів щодо ії походження. Ми зупинимось на найбільш поширених сучасних теоріях виникнення та еволюції гексаплоїдних видів пшениці та спельти зокрема. Оскільки гексаплоїдні види походять від тетраплоїдних, першочергове завдання - виявлити той тетраплоїдний вид, який дав початок первинному гексаплоїду. Серед можливих первинних тетраплоїдних видів пшениці, що могли відіграти провідну роль, виділяють такі стародавні види як T. dicoccoides, T. dicoccum, T. durum, T. carthlicum, T. ispahanicum, T. thimopheevii чи навіть припускають можливість поширення в минулому гіпотетичних видів T. parvicoccum чи $T$. protopersicum, які в результаті спонтанної гібридизації пшениці з носієм геному D ssp. strangulata Ae. squarrosa (Ae. tauschi), що, швидше за все, відбулась у районі Родючого півмісяця, дали початок гексаплоїдним видам пшениці (Zhukovskij, 1971; Goncharov, 2009) (рис. 1). Що стосується первинного гексаплоїдного виду, то і на це питання однозначності поглядів немає. Нині більшість учених схиляється до теорії походження голозерних гексаплоїдних видів пшениці від плівчастих (T. spelta L., T. macha Dek. et Men.) шляхом накопичення мутацій (Kuckuck, 1959), або спадково закріпленої зупинки на кінцевих етапах розвитку в онтогенезі як біологічному механізмі доместикації пшениці - явище неотенії в культурних рослин (Boguslavsky, 2008). Однак існують припущення, що ці дві групи гексаплоїдних пшениць (голозерні та плівчасті) могли розвиватись $і$ паралельно, тобто мали поліфілетичне походження або навіть виводять плівчасті види від голозерних. Такі припущення базуються на відсутності археологічних та лінгвістичних даних, які б 
указували на більш раннє існування спельти порівняно з м'якою пшеницею. Археологічним знахідкам T. spelta з Близького Сходу близько 8 тис. років (Kislev, 1984); тоді як знайдені залишки м'якої пшениці старші за них на тисячу років (Nesbitt, 2001; Goncharov, 2009). Втім, більшість авторів припускають, що плівчаста пшениця T. spelta - найдавніший гексаплоїдний вид, від якого утворилися всі інші види, у тому числі пшениця м'яка (Hopf, 1983; Luo et al., 2007). Проте, зважаючи на значні відмінності у будові між європейським підвидом спельти та азійським (за типом ламкості колосу, будовою колоскових лусок), і відсутність археологічних залишків спельти на шляху з Азії в Свропу, нині домінує погляд про незалежне походження підвидів цієї пшениці.

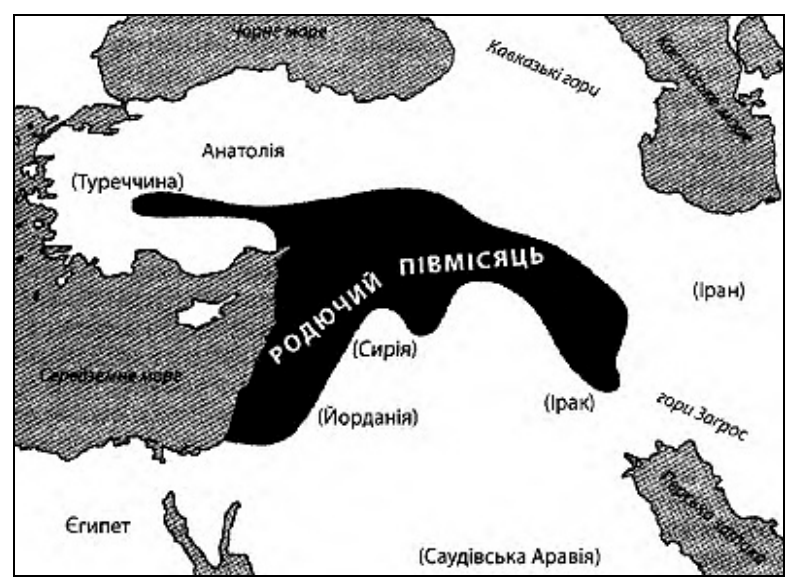

Рис. 1. Територія Родючого Півмісяця (дані Diamond, 2009)

Першим припущення про передньоазійське походження спельти висловив М. І. Вавилов (1926). Однак Е. Tschermak, J. Percival та інші зареєстрували факти відгалуження спельти під час міжвидової гібридизації, які переконали М. І. Вавилова у вторинному гібридному походженні європейської спельти (Vavilov, 1992; Dvorak et al., 2011). Гіпотезу про первинне азіатське походження спельти підтримує низка авторів (Kuckuck \& Schiemann, 1957; Zonary \& Hopf, 2000), які вважають азіатську спельту родоначальницею пшениці м'якої.

Стосовно європейської спельти, вона могла мати інше походження (Dvorak et al., 2006), тобто була продуктом гібридизації тетраплоїдної пшениці T. dicoccum, (AABB) та Ae. squarossa (DD). Існує гіпотеза (Bertsch, 1943) про походження європейської спельти від схрещування між T. compactum Host. (AABBDD) i T. dicoccum Schrank. (AАBB) на початку бронзового віку. Отримані повністю фертильні типи спельти від схрещувань T. compactum Host $\times T$. dicoccum Schrank можуть слугувати на користь цього припущення (Ohtsuka, 1998). Аналізуючи міжвидові гібриди пшениці, В. Ф. Дорофєєв також зробив висновок на користь вторинного поліфілетичного походження азійської та європейської спельти. На поліфілетичне походження спельти вказує географічна локалізація генів відновлення фертильності, гібридного некрозу та хлорозу (Dorofeev et al., 1987). Спельта Іспанії містить ген Ch2, а також гени Ne1 спельт Центральної Свропи та $\mathrm{Ne} 1$ i Ch2 спельт Ірану й Азербайджану. Також, за результатами порівняльного аналізу генів гібридного некрозу та хлорозу зразків спельти з різних еколого-географічних зон (Tsunewaki, 1971) установлено, що спельта європейського походження та інші важкообмолочувані види пшениці, подібно до T. тасha, походять від різних пентаплоїдних гібридів, отриманих від схрещувань між тетраплоїдним T. dicoccum і гексаплоїдним T. aestivum. Аналіз генів високомолекулярних глютенінів європейських і азійських зразків спельти, м'яких і твердих пшениць (Blatter et al., 2004), виявив різний географічний розподіл ß-алелів Glu-B1-1 i Glu-A1-2, що підтвердило незалежне походження європейської та азіатської спельти (Blatter et al., 2004; Dvorak \& Luo, 2006). Аналіз шести субодиниць високомолекулярного глютеніну виявив, що алелі Glu-B1-1, Glu-A1-2 i Glu-B1-2 стародавньої спельти та сучасної аборигенної швейцарської спельти відрізнялися від алелів глютенінкодувальних локусів хромосом стародавніх і сучасних м'яких пшениць (Blatter et al., 2002). Причому спельтоїдний алель Glu-B1-1 зчеплений з алелем ß-субкластера, який ідентифікований переважно в тетраплоїдних видів пшениці (Brown, 1999), тоді як алелі глютенінкодувальних локусів D-геному спельти та пшениці м'якої не відрізняються (Blatter et al., 2004).

Одержані дані підтверджують гіпотезу про те, що європейська спельта утворилася в результаті інтрогресії тетраплоїдної пшениці в гексаплоїдну легкообмолочувану м'яку пшеницю. Вивчення глютенінкодувальних локусів стародавньої спельти свідчить, що ß-алелі Glu-B1-1 i Glu-A1-2 існують щонайменше 300 років (Blatter et al., 2004). Спельта містить специфічні алелі $\alpha$-гліадинів ß-геному, відмінні від алелів тетраплоїдної пшениці. ß-Алель Glu-B1-V тетраплоїдної пшениці відрізняється від $\beta$-алеля Glu-B1-VI європейської спельти двома мутаціями (Blatter et al., 2004). Припускають, що європейська спельта отримала $\beta$-алелі високомолекулярного глютеніну від вихідної тетраплоїдної пшениці. Вивчення складу субодиниць глютенінів європейських спельт, а також споріднених тетраплоїдних і гексаплоїдних видів роду Triticum підтверджує гіпотезу вторинного походження європейської спельти (Yan et al., 2003). Що стосується субодиниць низькомолекулярного глютеніну, мінливість LMW-глютеніну у спельти вища порівняно з іншими видами (Caballero et al., 2004). Мінливість С-зони низькомолекулярного глютеніну спельти вища, ніж у T. tauschii (Gianibelli et al., 2002) і пшениці твердої (Nieto-Taladriz et al., 1997) і нижча, ніж у диплоїдних видів пшениці (Gianibelli et al., 2002).

На відміну від європейських зразків спельт, поділ глютенінкодувальних алелів між азійськими спельтами та пшеницею м'якою можна допустити лише якщо азійські спельти походять від висхідної плівчастої пшениці м'якої. Склад високо- та низькомолекулярних субодиниць глютенінів іранської спельти більше подібний до пшениці м'якої. Окремі європейські спельти містять компоненти гліадину та алелі генів некрозу, які відрізняються від іранської спельти (Campbell, 2007). На користь генетичної спорідненості спельти та пшениці м'якої свідчать подібність структури каріотипів і розподіл гетерохроматинових ділянок хромосом (Dedkova, 2008). Результати С-бендингу вказують на те, що T. spelta займає проміжне місце між тетраплоїдними та гексаплоїдними видами пшениць (Dedkova, 2008).

Поділ спельти на азійський i європейський підвиди підтверджений результатами С-диференційного забарвлення хромосом, а також технологіями штучних нейронних мереж (Dedkova, 2008). Засвідчено поділ європейської спельти на іспанську та власне європейську групи.

Отже, найвірогідніша - гіпотеза поліфілетичного походження спельти (рис. 2). Вона передбачає, що азійська спельта вперше виникла на каспійському узбережжі Ірану та стала родоначальником пшениці м'якої, а європейська - продуктом гібридизації м'якої та тетраплоїдної пшениці (Salamini et al., 2002).

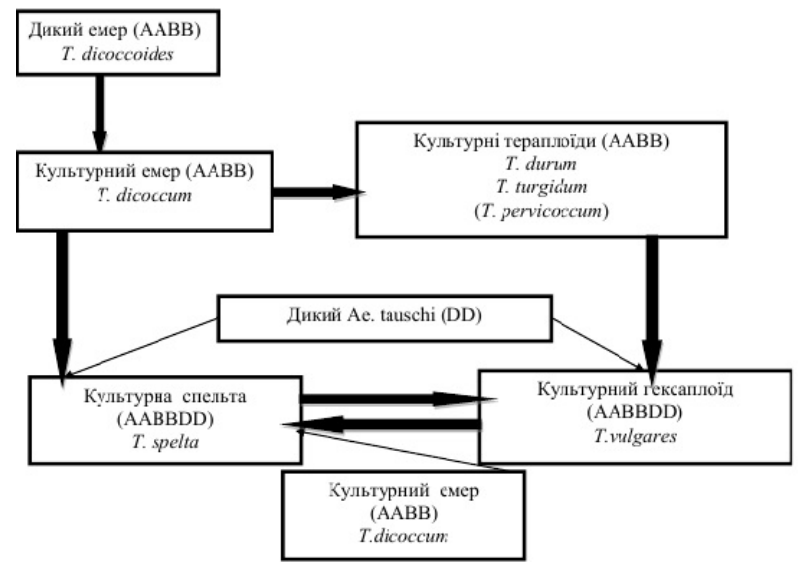

Рис. 2. Схема еволюції поліплоїдних видів пшениць у результаті окультурення (дані Salamini et al. (2002)) 
Проаналізувавши дані літератури стосовно походження спельти, можна зазначити, що це питання перебуває в полі зору багатьох вітчизняних і зарубіжних учених і потребує подальших досліджень. Зважаючи на ймовірне поліфілетичне походження азійської та європейської спельт, розглянемо історію їх поширення та вирощування.

Як зазначалось раніше, археологічні дослідження вказують на існування спельти близько VI тисячоліття до н. е. в Іраку, що відповідає часу неоліту. Експедиція H. Kuckuck, проведена в середині XX століття, виявила чисті посіви спельти на плоскогір'ї Східно-Центрального Iрану (Kuckuck \& Schiemann, 1957). Ізольовані посіви спельти або її домішки серед м'якої пшениці знайдені в інших районах Центральної Азії та Закавказзя (Азербайджан, Вірменія, Таджикистан, Туркменистан) (Dorofeev et al., 1987; Zohary, 2004).

Що стосується європейської спельти, дані вказують на іï появу в Центральній Свропі в ранньому бронзовому віці (Andrews, 1964; Nesbitt, 2001), тоді як зерна голозерних м'яких пшениць були знайдені в Європі вже на початку неоліту. Отже, в Свропі голозерна м'яка пшениця з'явилася раніше за спельту. За археологічними даними, поширення спельти обмежене саме територією Центральної Свропи (Nesbitt \& Samuel, 1996). Щодо Центральної Європи, на яку вказував Фляксбергер (1935) як на область найдавнішої культури спельти, то на всій іiі території (Hiмеччина, Австрія, Угорщина), де проведено велику кількість археологічних розкопок, спельта не знайдена. Лише у Швейцарії $\epsilon$ низка знахідок T. spelta у залишках бронзового віку (Fljaksberger, 1935; Nesbitt, 2001). Основне поширення спельти у стародавній Європі пов'язане перш за все 3 місцями проживання германських племен, звідки вона після завоювання Римською імперією цих територій поширилась в інші європейські країни. На теритоpiї України вирощування спельти, як і полби, пов'язують із населенням буго-дністровської культури, яку датують близько 5-6 тис. років до н. е. (Pashkevich \& Videjko, 2006; Poltoretskyi et al., 2018).

У першій половині XX століття спельта широко вирощувалась в Іспанії (Астурія), Німеччині, Австрії, Швейцарії та Бельгії. Ареал іiі поширення пов'язаний із гірськими районами 3 достатнім зволоженням. Спельта охоплювала гірські області ПівнічноЗахідних Алып із Вогезами, Шварцвальдом, заходячи у Тюрінгервальд і Швабську Юру. У Швейцарії - на північ від хребта Berner Alpen i Todi-Kette в кантонах Цюріх і Берн. Особлива група ярої остистої спельти збереглась в Астурії (Іспанія, Північні відроги Кантабрійських гір). Як і полба, з широким упровадженням сучасних технологій вирощування на початку минулого століття спельта швидко перетворюється на «острівну культуру», що вирощується на обмеженій території в місцях із традиційним укладом. Проте в останні десять років ситуація почала змінюватись, і нині попит на спельту суттєво зріс, вона 3 категорії просто малопоширених ботанічних видів перейшла в розряд нішевих. Нині спельта за посівними площами посідає третє місце серед пшениць, iіi почали активно вирощувати не лише на традиційній для неї території, а й на території Франції, Італії, Ізраїлю, США, Австралії (Tverdohlib \& Boguslavs'kij, 2013). Збільшились посіви під цією культурою і на території України, де сільгоспвиробники вирощують її переважно на експорт.

\section{Генетичне різноманіття, біологічні} та господарсько-цінні ознаки спельти

Пшеницю спельту (Triticum spelta L.) відносять до плівчастих пшениць і називають полбою або справжньою полбою. Щоб уникнути подальшої плутанини, доцільно полбою називати тільки двозернянку $T$. dicoccum $(2 \mathrm{n}=28)$ як первісну назву цієї пшениці, а для T. spelta залишити назву «спельта», (Dorofeev et al., 1987). Спельта (T. spelta L.) - гексаплоїдний вид пшениці (2n = $42)$, iї геном - $\mathrm{A}^{\mathrm{u}} \mathrm{BD}$. Має форми ярого та озимого типу розвитку. Рослини спельти зазвичай високорослі, колоси довгі, вузькі, за достигання ламкі, зернівки продовгуваті, тісно охоплені лусками. Ця зернова культура була розповсюджена в давні часи, ві- дома з епохи раннього неоліту. Вона була поширена в Свропі та Азії. Людство тисячоліттями харчувалось цим злаком (Podprjatov \& Jashhuk, 2013; Poltoretskyi et al., 2018). Відмова від вирощування плівчастих видів пшениці зумовлена декількома причинами. По-перше, вирощувані форми майже винятково являють собою продукти народної селекції: це екстенсивні сорти, витривалі до суворих умов, але з обмеженим потенціалом продуктивності. По-друге, полба та спельта мають ознаки, що ускладнюють застосування засобів механізації під час вирощування та переробки врожаю: ламкість колоса при достиганні, яка спричиняє втрати врожаю, та плівчастість, що вимагає додаткових витрат енергії та праці для шеретування та очищення зерна, а також більшого обсягу сховищ порівняно 3 голозерною пшеницею. Плівчастість також не дає змоги провести якісну сівбу зерновими сівалками, оскільки невимолочені колоски забивають насіннєпроводи, а спроби вимолотити їх до одержання чистого зерна викликають пошкодження зернівок, внаслідок чого знижується схожість. Була ще одна причина, можливо, навіть найбільш вагома: під час переходу до обробки грунту бороною стало неможливим утримувати колоски, бо вони чіплялися за зубці борони та виходили на поверхню. 3 іншого боку, плівчастість позитивна ознака, оскільки під час сівби та проростання луски захищають зернівку, а потім і проростки від впливу негативних чинників природного середовища, що сприяє формуванню здорових та міцних сходів. Невимолочене зерно у лусках («ворох») добре зберігається завдяки нещільному приляганню колосків один до одного, що зменшує перегрів зерна. Плівчастість - також додатковий захист від пошкодження птахами та комахами (Pukhalskiy et al., 2008; Tverdohlib et al., 2013).

Як зазначалось вище, за походженням спельта поділяється на два підвиди: європейську та азійську (Hospodarenko et al., 2016). Оскільки в наших умовах практичне значення мають різновиди європейського підвиду спельти, ми зупинимось, у першу чергу, на їх характеристиці. Європейська спельта (subsp. spelta) поділяється на дві еколого-морфологічні групи: західноєвропейська (німецька, баварська) та астурійська (іспанська, іберійська). У складі першої групи переважають озимі форми, у другої - ярі (Alvarez \& Guzmán, 2013). Відмінні для цих груп - окремі ознаки колоса. Західноєвропейські форми в основному представлені безостими різновидами, а астурійські - завжди остисті (Dorofeev et al., 1987). Азійська спельта характеризується наявністю як озимих, так і ярих форм.

Серед корисних ознак спельти варто відмітити невибагливість, здатність зростати на бідних гірських грунтах, значну зимостійкість, стійкість до надлишкового зволоження. На грунтах важкого гранулометричного складу, в умовах значної кількості опадів, холодної зими та високогір'я (до 1000 м), порівняно з пшеницею м'якою спельта дає стабільно високий урожай (Schmitz, 2006). Спельта - волого- та світлолюбива культура, тому стійкість до атмосферної та грунтової посухи в неї слабка, а продуктивне кущіння та облистяність - сильні. Іберійська спельта стійка до бурої та жовтої іржі, баварська спельта не стійка до грибкових захворювань. У багатьох зразків відмічено стійкість до видів-збудників фузаріозу. Спельті притаманна сприйнятливість до летючої сажки, особливо до рас, що вражають м'яку пшеницю; слабкосприйнятливі та стійкі зразки малопоширені (Dorofeev et al., 1987).

Західноєвропейські форми на початкових стадіях відзначаються сповільненим темпом розвитку. Німецька спельта екологічно досить одноманітна (Schmitz, 2006). Вона пристосована до гірських і передгірних районів, відрізняється відносно тривалим вегетаційним періодом, волого- та світлолюбива, з низькими вимогами до технології вирощування.

Під час дослідження впливу короткотривалої гіпертермії та грунтової посухи на морфофізіологічні процеси у рослин $T$. spelta сорту Франкенкорн - представника европейської групи, показано, що вплив обох стресорів викликав зменшення маси та довжини пагонів і кореневої системи, проте вираженіші зміни зареєстровані після дії грунтової посухи. За морфометричними 
показниками корені виявилися чутливішими до гіпертермії, ніж пагони. За гіпертермії та грунтової посухи зафіксовано зменшення вмісту фотосинтетичних пігментів. Грунтова посуха та гіпертермія істотно не впливають на мікроструктуру епідерми листкової пластинки. Разом із тим, зростає щільність воску на листковій пластинці (Kosakisvska et al., 2017). На рівні ультраструктури короткочасна гіпертермія викликала часткову деструкцію тилакоїдних мембран хлоропластів. Спостерігалася хвилеподібна упаковка тилакоїдів гран, значне розширення люменальних проміжків, відрив термінальних кінців тилакоїдів один від одного. За гіпертермії мітохондрії помітно «розбухали», при цьому мембрани крист ставали менш контрастними. Спостерігалося часткове просвітлення матриксу органел. Зростала також їх кількість порівняно з контролем. В ядрі виявлено порушення в конденсації хроматину. У цитоплазмі клітин зростала кількість ліпідних крапель. Короткочасна гіпотермія викликала інтенсивне утворення пластоглобул, збільшення кількості та розміру крохмальних зерен. Однак деструкції тилакоїдних мембран не спостерігалося. Частина мітохондрій набувала округлої форми (40\%) i мала розміри, близькі до контролю, 26\% органел мали лінзоподібну, 16\% - «гантелеподібну» і 18\% - «чашоподібну» форму. Форма мітохондрій належить до динамічних структурних показників (Van Gestel \& Verbelen, 2002; Logan, 2010). У теплолюбних рослин їі зміна супроводжується зникненням крист, що розглядається як симптом пошкодження (Krasch \& Wise, 2000). У холодостійких рослин, таких як арабідопсис або пшениця, зміна форми мітохондрій на витягнену «гантелеподібну» та «чашоподібну» має обернений характер (Yu et al., 2011; Vella et al., 2012). Передбачається, що така форма органел сприяє збільшенню площі їх поверхні та полегшує обмін метаболітами з цитоплазмою (Yu et al., 2011; Vella et al., 2012). У працях інших учених показано, що збільшення розмірів мітохондрій за короткочасного стресу свідчить про підвищення дихальної здатності клітини (Armstrong et al., 2006; Venzhik et al., 2017). Такі зміни форми мітохондрій зумовлені складом, головним чином, ненасичених жирних кислот (Theocharis et al., 2012). Така реакція клітин мезофілу листка T. spelta на дію екстремальних температур виражається у структурно-функціональній реорганізації фотосинтетичного та енергетичного апарату, яка починається у перші години дії на рослину стресових температур і $\epsilon$ обов'язковою умовою реалізації адаптивних програм. Дослідження показали значну адаптацію сорту Франкенкорн до низьких позитивних температур (Schmitz, 2006).

Азійські та європейські спельти різняться морфологічною будовою. Luo (2000) доводить, що це зумовлено генами, які контролюють морфологію колоса. Більш ламкий колосовий стрижень мають європейські спельти (Dorofeev et al., 1987), які генетично споріднені до пшениці м'якої (Dvorak et al., 2006). Водночас інші вчені (Liu \& Tsunewaki, 1991) наголошують, що європейська спельта та пшениця м'яка відрізняються генами, які відповідають за ламкість колосу та лусок. В азійської спельти членик стрижня прикріплений до основи колоска своєю верхньою частиною. Іберійська спельта, стійка до бурої та жовтої іржі, в аграрному виробництві представлена лише ярими формами. Баварська спельта нестійка до грибкових захворювань і представлена озимими пізньостиглими формами (Dorofeev et al., 1987). Серед досліджуваних різновидностей спельти тільки зразки 3 Ірану та Туркменистану, в яких налив зерна відбувається за умови підвищеної температури повітря, містять ген гібридного некрозу Vm3. Більшість європейських зразків спельти $(57,9 \%)$ містять ген гібридного некрозу Vm2. Подібна закономірність установлена і для м'якої пшениці: в європейських сортів присутній ген Vm2, а ген Vm3 характерний для азійських м'яких пшениць. Для азійських зразків спельти характерний ген $\mathrm{Ne1}$, а для європейських - ген Ne2 (Goncharov, 2008). Подібний розподіл генів гібридного некрозу спостерігається у пшениці м'якої (Pukhalskiy et al., 2008). Так, ген Ne2 містять більшість європейських сортів, при цьому в них переважають генотипи Ne1Ne2 i Ne1ne2. Необхідно також зазначити, що у спельти, яка росте на території
Німеччини, Швейцарії, Австрії, Чехії, а також на південному сході Іспанії, відсутні гени гібридного некрозу.

Друга, не менш важлива особливість спельти, ніж витривалість до умов вирощування, - якість ії зерна, що також сприяло поверненню цієї культури на сучасний ринок. Зерно спельти використовують переважно для випікання хліба, хоча, як будь-яка зернова культура, вона може використовуватись і для одержання крупи чи борошна (Liubych et al., 2017). Спельта високо цінується своїми харчовими перевагами зерна. Воно має вищу порівнянно $з$ м'якою пшеницею енергетичну цінність, а перетравність білка спельти перевищує 80\%. Збалансована за амінокислотним складом, містить більше бета-каротину, ретинолу, на 30-60\% більше вітамінів, ніж у м'якій пшениці; має більш розтяжну клейковину, але менш еластичну, ніж у м'якої пшениці. Борошнистий ендосперм має високий вміст білка (до 25\%, для порівняння у м'якої пшениці - 8-10\%) і високу в'язкість (Podprjatov \& Jashhuk, 2013; Liubych et al., 2017). Спельта багатша, ніж пшениця м'яка, на протеїн, ненасичені жирні кислоти та клітковину, однак вона слабка, тому борошно спельти використовується як домішка під час випікання хліба. Завдяки високій водоутримувальній здатності борошна хліб зі спельти довго не черствіє (Osokina et al., 2018). Клейковина спельти містить менше білкових компонентів, які провокують целіакову хворобу. Вчені зі Швейцарії встановили, що всі продукти зі спельти (хліб, макарони, крупи) сприяють зміцненню імунної системи. Це зумовлено наявністю в зерні особливих розчинних вуглеводів - мікополісахаридів (Podprjatov \& Jashhuk, 2013).

Кормове, а також технологічне значення має солома спельти. У деяких публікаціях висвітлюються досягнення розвинених країн у використанні зернових культур для виготовлення екологічно чистих меблів із пресованої соломи.

\section{Використання спельти у селекційній роботі}

Інтрогресія генетичного матеріалу від дикорослих родичів до геному м'якої пшениці залишається актуальною, оскільки являє собою природне та невичерпне джерело збагачення генофонду пшениці за генами, що поліпшують іiі адаптивний потенціал (Iefimenko et al., 2018). У вітчизняній та світовій практиці існує багато прикладів успішного використання різних екотипів спельти в селекції та наступній гібридизації з голозерними пшеницями 3 метою поліпшення останніх і надання їм стійкості до абіотичних та біотичних стресорів, підвищення якісних показників зерна (Golik et al., 2016). Ще M. I. Вавилов для поліпшення харчових цінностей пшениці м'якої пропонував використовувати у схрещуваннях спельту як партнера (Vavilov, 1935). За структурою каріотипу та розподілом гетерохроматичних сегментів на хромосомах спельта не відрізняється від м'якої пшениці, однак вона характеризується вищим рівнем внутрішньовидового поліморфізму за хромосомними перебудовами (інверсіями та транслокаціями). Відповідно до розподілу гетерохроматичних районів спельта займає проміжне положення між тетраплоїдними та гексаплоїдними видами пшениці (Chekalin et al., 2008).

Починаючи 3 другої половини ХІХ сторіччя і донині, спельту використовують як джерело спадкової основи низки господарсько-цінних ознак (Dorofeev et al., 1987; Golik et al., 2016). Схрещування пшениці м'якої зі спельтою дозволяє отримати нові форми пшениці спельти, в яких можна очікувати поліпшення показників якості за рахунок інтрогресії в їх генотип генетичного матеріалу пшениці м'якої (Diordicva \& Eshhenko, 2016). У першій половині ХХ ст. у Центральній Європі вирощували місцеві сорти з Австрії та Німеччини, а також створені простим добором із них: Oberkulmer Rotkorn, Schwabenkorn, Bauerlaender, Ostro, Holstenkorn, Frankenkorn тощо. Серед сортів, створених останнім часом у Сербії, - озимі Nirvana, NSS 3/01, NSS 6/01, NSS 1/02; в Італії - ярі B1030, S2013, S2070, Р12; у Канаді озима Heritage та ярі CDC Nexon, CDC Origin, CDC Zorba; y США - Lentz Spelt, Frank. Останніми роками в Росії створений i проходить держсортовипробування озимий сорт Алькоран. В Інсти- 
туті рослинництва ім. В. Я. Юр'єва розмножується для передачі на сортовипробування сорт ярої спельти. В Україні створення перших вітчизняних сортів спельти започаткував Ф. М. Парій. Він на базі Всеукраїнського наукового інституту селекції (ВНIC) спільно 3 Уманським національним університетом садівництва (УНУС) створив сорти озимої спельти з полегшеним вимолотом зерна, врожайністю до 6 т/га, вмістом білка понад 20\% і широко адаптованих до природно-кліматичних умов України. До реєстру сортів рослин України занесено два сорти спельти: Зоря України та Європа, ще один - Альберта - зараз проходить державне сортовипробування (Parij et al., 2013). Розглянемо характеристики внесених до реєстру сортів детальніше.

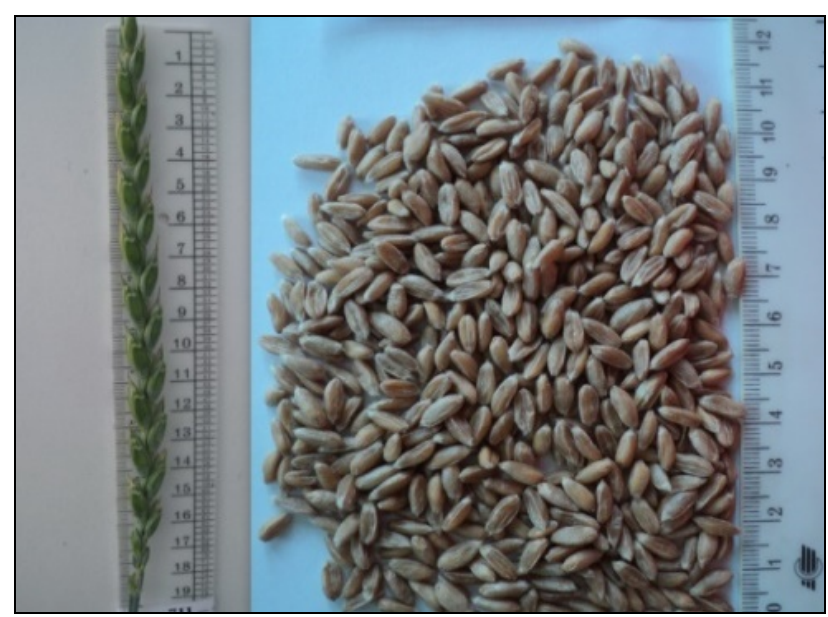

Рис. 3. Колос та зерно T. spelta сорту Зоря України

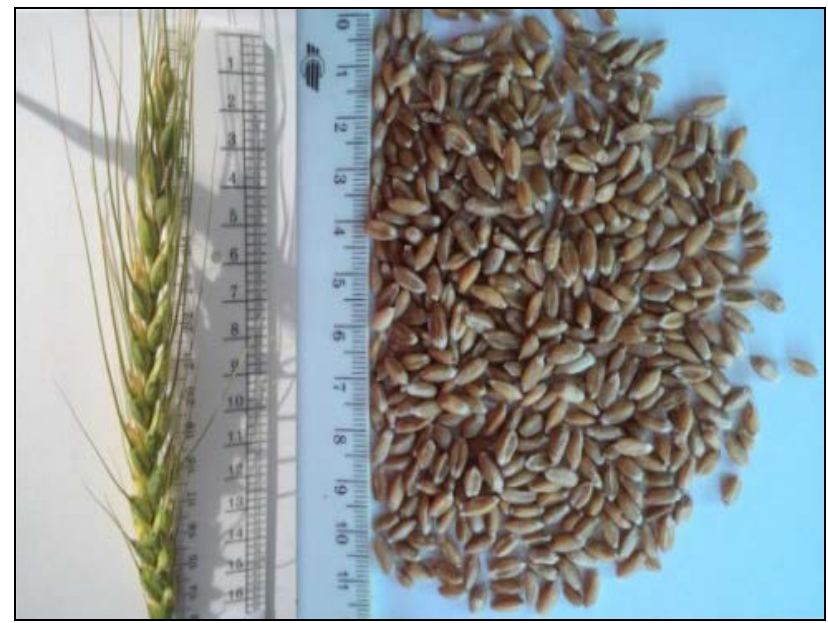

Рис. 4. Колос та зерно T. spelta сорту Європа

Зоря України (рис. 3) - перший сорт озимої спельти, занесений до Державного реєстру сортів України. Сорт створено в результаті добору з місцевої популяції стародавнього сорту спельти, що вирощувався в Карпатах. Придатний для органічного землеробства екстенсивного типу, показує високу врожайність за інтенсивної технології вирощування. Як і більшість спельт, має ламкий, видовжений (до 16 см) і нещільний колос із кількістю зерен 48 шт. i масою 1000 зерен 43,5-45,0 г. Середня врожайність за роки випробування - 5,5 т/га, а потенційна - 6,2 т/га. Сорт пізньостиглий. Невибагливий до умов вирощування, має підвищену зимостійкість (8,2-8,7 бала), високою посухостійкістю та стійкістю до вилягання та осипання. Висота - 110-120 см. Стійкий до основних хвороб пшениці: бурої іржі, борошнистої роси, фузаріозу. Для сорту притаманне оптимальне поєднання врожайності з високими якостями зерна. У зерні цього сорту міститься 18-22\% білка та 48-49\% сирої клейковини, що більше, ніж у будь-яких голозерних сортів із реєстру сортів України. Натура зерна 650 г/л. Сорт добре показав себе в усіх грунтово-кліматичних зонах України, рекомендований до вирощування у Степу, Лісостепу та Поліссі (The state register of plant ..., 2015).

Європа (рис. 4) - інший сорт озимої спельти, створений ВНІС і УНУС, - результат схрещування спельти із м'якою пшеницею. Від спельти сорт успадкував високу якість зерна, адаптивний потенціал, а від м'якої пшениці - високу урожайність і легкий обмолот зерна. Придатний для органічного землеробства екстенсивного типу. На відміну від Зорі України, сорт Європа має дещо вищу середню $(5,8 \mathrm{~T} /$ га) та потенційну урожайність $(6,5 \mathrm{t} / \mathrm{ra})$, хоча поступається першому сорту якісними показниками зерна. У зерні сорту Європа вміст білка складає $18-20 \%$, сирої клейковини $40-45 \%$, сирого протеїну 20-22\% із натурою 670 г/л. Як і сорт Зоря України, Свропа - високостійкий сорт до основних хвороб і несприятливих чинників навколишнього середовища. Рекомендований для вирощування в усіх природно-кліматичних зонах України (The state register of plant ..., 2015).

\section{Висновки}

Визначено два напрями селекційної роботи зі спельтою: відродження іiї як самостійної культури та використання як джерела господарсько-цінних ознак у селекційних програмах із м'якою пшеницею (Hospodarenko et al., 2016; Liubych et al., 2017). Нині селекцією спельти займаються як вітчизняні, так і зарубіжні вчені. Серед вітчизняних установ найбільшого практичного результату в селекційній роботі зі спельтою досягли Всеукраїнський науковий інститут селекції, Уманський науковий інститут садівництва та Інститут рослинництва ім. В. Я. Юр'єва, в яких уже створені сорти, внесені до Державного реєстру сортів України.

Висока продуктивність $T$. aestivum забезпечується завдяки умовам культивування: тривалому та теплому вегетаційному періоду з м'якою зимою, зрошенню, багатим мінеральними речовинами грунтам. В Україні з їі досить суворими та різноманітними агрокліматичними умовами вирощування зернових культур досить складна та ризикована справа. Спельта здатна давати стабільні врожаї без суворого дотримання технології виробництва у багатьох господарствах нашої країни і може бути прекрасною альтернативою пшениці м'якій. Зважаючи на те, що останніми десятиріччями в Україні, як і в інших країнах, зростає попит на спельту як до культури органічного землеробства та джерела «органічної або здорової їжі» («organic / health food»), вирощування цієї культури стає привабливим в умовах ринкової економіки. Тому сподіваємось, що узагальнені матеріали з питань генетики, біології, походження та поширення спельти, іiі господарсько-цінні ознаки та інші характеристики стануть у нагоді науковцям-практикам, які планують займатись вирощуванням чи впровадженням спельти.

Робота виконана в рамках проекту№ III-82-17.454 «Фітогормональна система нових генотипів Triticum aestivum L. та іiї диких попередників за дії екстремальних кліматичних факторів» (2017-2021 рр.), що фінансується Національною академією наук України.

\section{References}

Alvarez, J. B., \& Guzmán, C. (2013). Spanish Ancient Wheat: A genetic resource for wheat quality breeding. Advances in Crop Science and Techno$\operatorname{logy} 1(1), 1-7$.

Andrews, A. C. (1964). The genetic origin of spelt and related wheats. Der Züchter, 34, 17-22.

Armstrong, A. F., Logan, D. C., Tobin, A. K., O’Toole, P., \& Atkin, O. K. (2006). Heterogeneity of plant mitochondrial responses underpinning respiratory acclimation to the cold in Arabidopsis thaliana leaves. Plant Cell Environment, 29(5), 940-949.

Blatter, R. H. E., Jacomet, S., \& Schlumbaum, A. (2002). About the origin of European spelt (Triticum spelta L.): Allelic differentiation of the HMW Glutenin B1-1 and A1-2 subunit genes. Theoretical and Applied Genetics, 108(2), 360-367.

Blatter, R. H. E., Jacomet, S., \& Schlumbaum, A. (2002). Spelt-specific alleles in HMW glutenin genes from modem and historical European spelt (Triticum spelta L.). Theoretical and Applied Genetics, 104(2-3), 329-337. 
Boguslavsky, R. L. (2008). O biologicheskih mehanizmah domestikacii pshenici [About mechanisms of wheat domestication]. Vesnik Vavilovskogo Obshchestva Selektsionerov i Genetikov, 12(4), 680-685 (in Russian).

Bohuslavskyi, R. L., \& Golik, O. V. (2001) Henetychni resursy kulturnoyi dvozernyanky Triticum dicoccum Schrank (Schuebl.) dlya selektsiyi pshenytsi v Ukrayini [Genetic resources of the cultivar Triticum dicoccum Schrank (Schuebl.) for wheat selection in Ukraine]. Selektsiya i Nasinnytstvo, 85, 72-83 (in Ukrainian).

Brown, T. A. (1999). How ancient DNA may help in understanding the origin and spread of agriculture. Philosophical Transactions of the Royal Society of London. Series B, 354(1379), 89-98.

Caballero, L., Martin, L. M., \& Alvarez, J. B. (2007). Agrobiodiversity of hulled wheats in Asturias (North of Spain). Genetic Resources and Crop Evolution, 54(2), 267-277.

Chekalin, M. M., Tishhenko, V. M., \& Batashova, M. E. (2008). Selekciya ta genetika okremih kul'tur [The selection and genetics of individual crops]. FOP Govorov, Poltava (in Ukrainian).

Dedkova, O. S., Badaeva, E. D., Mitrofanova, O. P., Zelenin, A. V., \& Pukhalskiy, V. A. (2004). Analysis of intraspecific divergence of hexaploid wheat Triticum spelta L. by C-banding of chromosomes, 40(10), 1111-1126.

Derzhavnyj rejestr sortiv roslyn, prydatnyh dlja poshyrennja v Ukraini na 2015 rik [State register of plant varieties suitable for distribution in Ukraine for 2015]. Kyiv (in Ukrainian).

Diamond, J. (2009) Zbroya, mikroby i kharch: Vytoky nerivnostey mizh narodamy [The arms, microbes and food: The origins of differences between peoples]. Nika-Tsentr, Kyiv (in Ukrainian).

Dixon, J., Braun, H. J., Kosina, P. P., \& Crouch, J. (2009) Wheat facts and futures. CIMMMYT, Mexico.

Dorofeev, V. F., Udachin, R. A., \& Semenova, L. V. (1987). Pshenicy mira [Wheat of the world]. Agropromizdat, Leningrad (in Russian).

Dvorak, J., Akhunov, E. D., Akhunov, A. R., Deal, K. R., \& Luo, M. C. (2006) Molecular characterization of a diagnostic DNA marker for domesticated tetraploid wheat provides evidence for gene flow from wild tetraploid wheat to hexaploid wheat. Molecular Biology and Evolution, 23, 1386-1396.

Dvorak, J., Luo, M. C., \& Akhunov, E. D. (2011). N. I. Vavilov's theory of centers of diversity in the light of current understanding of wheat diversity, domestication and evolution. Czech Journal of Genetics and Plant Breeding, 47, 20-27.

Fari, J. (2015) Wheat domestication: Key to agricultural revolutions past and future. In: Tuberosa, R., Graner, A., \& Frison, E. (Eds.). Genomics of plant genetic resources. Springer, Netherlands.

Fljaksberger, K. A. (1935). Hlebnye zlaki, pshenitsa [The cereals, wheat]. Kulturnaja flora SSSR. Vol. 1, Gosudarstvennoje Izdatel'stvo Sovhoznoj i Kolhoznoj Literatury, Leningrad (in Russian).

Gianibelli, M. C., Echaide, M., Larroque, O. R., Carrillo, J. M., \& Dubcovsky, J. (2002). Biochemical and molecular characterization of Glu-1 loci in Argentinean wheat cultivars. Euphytica, 128(1), 61-73.

Golik, O. V., Tverdokhleb, E. V., Pozdnyakov, S. Y., Didenko, R. L., \& Boguslavsky, O. V. (2016). Plenchatye vidy pshenitsy dlja organicheskogo zemledelija [The fillet types of wheat for organic farming]. Fundamentalnyie i prykladnyie yssledovanyja v byoorganycheskom selskom hozjajstve Rossii, SNG i ES. Mezhdunarodnaja nauchno-praktycheskaja konferentsyja (9-12.08.2016). Moscow. 1, 368-378 (in Russian).

Goncharov, N. P. (2009) Opredelitel' raznovidnostej mjagkoj i tvjordoj pshenic [The determinant of varieties of soft and hard wheat]. Izd-vo RAN, Novosibirsk (in Russian).

Goncharov, N. P., \& Kondratenko, E. Y. (2008). Proishozhdenie, domestikacija i evoljucija pshenic [The origin, domestication and evolution of wheat]. Vestnik Vserossijskogo Obshhestva Genetikov i Selekcionerov, 12, 159-179 (in Russian)

Hospodarenko, H. M., Kostogryz, P. V., Lyubich, V. V., Pariy, M. F., Poltoretsky, I. A., Polianetsky, I. A., Ryabovol, L. A., Ryabovol, Y. S., \& Suhodum, V. G. (2016). Pshenytsya spelta [The wheat of spelt]. Stik Hrup Ukrayina, Kyiv (in Ukrainian).

Iefimenko, T. S., Antonyuk, M. Z., Martynenko, V. S., Navalihina, A. G., \& Ternovska, T. K. (2018). Introgression of Aegilops mutica genes into common wheat genome. Cytology and Genetics, 52(1), 21-30.

Ivashhenko, O. O., \& Ivashhenko, O. O. (2008). Shljahy adaptaciji zemlerobstva $\mathrm{v}$ umovah zmin klimatu [The ways of adapting agriculture in the context of climate change]. Zbirnik Naukovyih Prats Natcionalnogo Naukovogo Centru «Institut Zemlerobstva UAAN», Ekmo, Kyiv (in Ukrainian).

Kosakisvska, I. V., Babenko, L. M., Vasyuk, V. A., \& Voytenko, L. V. (2017) Vplyv gipertermiji ta gruntovoji posuhy na rist, vmist fotosyntetychnyh pigmentiv ta mikrostrukturu epidermisu listka Triticum spelta L. [Hyperthermia and ground drought effects on growth, content of photosynthetic pigments and epidermis microstructure in leaf of Triticum spelta L.]. The Bulletin of Kharkiv National Agrararian University. Series Biology, 42(3), 81-91 (in Ukrainian).
Kratsch, H. A., \& Wise, R. R. (2000). The ultrastructure of chilling stress. Plant, Cell and Enviroment, 23, 337-350.

Kuckuck, H. (1959). On the findings of Triticum spelta L. in Iran and on the arising of Triticum aeslivum-types through crossing of different speltatypes. Wheat Information Service, 3, 9-10.

Kuckuck, H., \& Schiemann, E. (1957). Über das Vorkommen von Spelz und Emmer (Triticum spelta L. und T. dicoccum Scübl.) im Iran. Zeitschrift für Pflanzenzüchtung, 38, 383-396.

Liubych, V. V., Hospodarenko, H. M., \& Poltoretskyi, S. P. (2017). Quality features of spelt wheat grain. Lap Lambert Academic Publishing, Saarbrücken.

Logan, D. C. (2010). Mitochondrial fusion, division and positioning in plants. Biochemical Society Transactions, 38, 789-795.

Luo, M. C., Yang, Z. L., \& Dvorak, J. (2000). The Q locus of Iranian and European spelt wheat. Theoretical and Applied Genetics, 100, 602-606.

Morgun, V. V., \& Major, P. S. (2009). Zimo- i morozostijkist' ozimih zlakovih kul'tur [Winter and frost resistance of winter cereals]. Fiziologija roslin Problemy ta perspektyvy rozvytku. Vol. 2. Logos, Kyiv (in Ukrainian).

Morgun, V. V., Dubrovna, O. V., \& Morgun, B. V. (2016). Suchasni biotehnologiji otrymannia stijkyh do stresiv roslyn pshenyci [Modern biotechnologies for obtaining stress-resistant wheat plants]. Fiziologija Rastenij i Genetika, 48(3), 196-214 (in Ukrainian).

Morgun, V. V., Sichkar, S. M., Pochinok, V. M., Golik, O. V., \& Chugunkova, T. V. (2015). Analiz struktury produktyvnosti kolekcijnyh zrazkiv maloposhyrenyh vydiv pshenyci [Analysis of the productivity structure of collection samples of rare wheat species]. Faktory Eksperymental'noji Evoliuciji Organizmiv, 16, 136-140 (in Ukrainian).

Nesbitt, M. (2001). Wheat evolution: Integrating archaeological and biological evidence. Wheat taxonomy: The legacy of John Percival, 3, Linnean, Special Issue. London Linnean Society. Pp. 37-59.

Nesbitt, M., \& Samuel, D. (1996). From staple crop to extinction? The archaeology and history of hulled wheats. In: Padulosi, S. (Ed.). Hulled wheats. Proceedings of the First International Workshop on Hulled Wheats. Int Plant Genet. Resources Institute, Rome.

Nieto-Taladriz, M. T., Ruiz, M., Martínez, M. C., Vázquez, J. F. \& Carrillo, J. M. (1997). Variation and classification of B low-molecular-weight glutenin subunit alleles in durum wheat. Theoretical and Applied Genetics, 95, 1155-1160.

Osokina, N., Liubych, V., Novak, L., Pushkariova-Bezdil, T., Priss, O., Verkholantseva, V., Hryhorenko, O., Pusik, V., \& Pusik, L. (2018). Elucidation of the mechanism that forms breadbaking properties of the spelt grain. Eastern European Journal of Enterprise Technologies, 2, 39-47.

Parij, F. M., Ljubich, V. V., \& Suhodum, O. G. (2013). Otsinka gospodars'ko cinnyh vlastyvostej novogo sortu pshenyci spelty ozymoji Zoria Ukrajiny [The evaluation of economic valuable properties of a new wheat variety spelled winter Zorya Ukraine]. Nasinnictvo, 125, 5-15 (in Ukrainian).

Pashkevich, G. O., \& Videjko, M. J. (2006). Rilnyctvo plemen Trypil's'koji kul'tury [The agriculture of tribes of Trypillian culture]. Kyiv (in Ukrainian).

Podprjatov, G. I., \& Jashhuk, N. O. (2013). Prydatnist' zerna pshenyci spelty ozimoji dlia hlibopekars'kih ta kormovyh cilej [The suitability of wheat grain for winter bread for baking and feed purposes]. Novitni Agrotehnologiji, 1(1), 71-79 (in Ukrainian).

Poltoretskyi, S., Hospodarenko, H., Liubych, V., Poltoretska, N., \& Demydas, H. (2018). Toward the theory of origin and distribution history of Triticum spelta L. Ukrainian Journal of Ecology, 8, 263-268.

Pukhalskiy, V. A., Bilinskaya, E. N., Obolenkova, G. A., Martynov, S. P., \& Dobrotvorskaya, T. V. (2008). New data on the distribution of hybrid necrosis genes in winter bread wheat (Triticum aestivum L.) cultivars. Russian Journal of Genetics, 44(2), 171-179.

Reynolds, M., Ortiz-Monasterio, J., \& McNab, A. (2001). Application of physiology in wheat breeding. D. F. Cimmyt, Mexico.

Salamini, F., Ozkan, H., Brandolini, A., Schäfer-Pregl, R., \& Martin, W. (2002). Genetics and geography of wild cereal domestication in the near east. Nature Reviews Genetics, 3(6), 429-441.

Schmitz, K. (2006). Dinkel - ein Getreide mit Zukunft. Backmittelinstitut Aktuell. Sonderausgabe, $1-8$

Skurdina, Z. M. (1992). Pshenica spelta: Sostojanie i perspektivy kul'tury v sovremennyh uslovijah za rubezhom [The wheat spelt: The state and prospects of culture in modern conditions abroad]. Agropromyshlennoe proizvodstvo: Opyt, problemy i tendencii razvitija. Zemledelie, rastenievodstvo, kormoproizvodstvo, plodoovoshhnoe hozjajstvo, zashhita rastenij. Moscow (in Russian).

Theocharis, A., Clement, C., \& Barka, E. A. (2012). Physiological and molecular changes in plants grown at low temperatures. Planta, 235, 1091-1105.

Tsunewaki, K. (1966). Comparative gene analysis of common wheat and its ancestral species. II. Waxiness, growth habit and awnedness. Japanese Journal of Botany, 19, 175-229.

Tverdohlib, O. V., \& Boguslavskij, R. L. (2012). Vydove riznomanittia pshenytsi, naprjamky i perspektyvy jogo vykorystannia [The species variety of 
wheat, directions and prospects of its use]. Zbirnik Naukovih Prac' Umanskogo NUS, 80(1), 37-47 (in Ukrainian).

Tverdohlib, O. V., Golik, O. V., Ninieva, A. K., \& Boguslavs'kij, R. L. (2013) Spelta i polba $\mathrm{V}$ organichnomu zemlerobstvi [Spelt and emmer in organic farming]. Posibnyk Ukrajins'kogo Hliboroba, 150-172 (in Ukrainian).

Van Gestel, K., \& Verbelen, J. P. (2002). Giant mitochondria a response to low oxygen pressure in cells of tobacco (Nicotiana tabacum L.). Journal of Experimental Botany, 53, 1215-1218.

Vavilov, N. I. (1935). Nauchnye osnovy selekcii pshenicy [The scientific foundations of wheat selection]. Moscow (in Russian).

Vavilov, N. I. (1992). Origin and geography of cultivated plants. Cambridge University Press, Cambridge.

Vella, G. F., Joss, T V., \& Roberts, T. H. (2012). Chilling-induced ultrastructural changes to mesophyll cells of Arabidopsis grown under short days are almost completely reversible by plant rewarming. Protoplasma, 249, 1137-1149.

Venzhik, Y. V., Titov, A. F., \& Talanova, V. V. (2017). Kratkovremennoe ohlazhdenie prorostkov ili kornej pshenicy vyzyvaet izmenenija v ul'trastruk- ture kletok mezofilla lista [Short-term chilling of wheat seedlings or roots affects the ultrastructure of mesophyll cells]. Trudy Karel'skogo Nauchnogo Centra RAN, 5, 66-78 (in Russian).

Yan, Y., Hsam, S. L. K., \& Yu, J. Z. (2003). HMW and LMW glutenin alleles among putative tetraploid and hexaploid European spelt wheat (Triticum spelta L.) progenitors. Theoretical and Applied Genetics, 107, 1321-1330.

Yu, J., Cang, J., Zhou, Z., \& Liu, L. (2011). Anatomical structure composition between leaves of two winter wheat cultivars with different cold/freezing tolerance under low temperature stress. Journal of Northeast Agricultural University, 18, 1-3.

Zhukovskij, P. M. (1971). Kul'turnye rastenija i ih sorodichi [The cultivated plants and their relatives]. Kolos, Leningrad (in Russian).

Zohary, D. (2004). Unconscious selection and the evolution of domesticated plants. Economic Botany, 58, 5-10.

Zohary, D., \& Hopf, M. (1993). Domestication of plants in the old world: The origin and spread of cultivated plants in West Asia, Europe, and the Nile Valley. Claren Press, Oxford. 